\title{
Clinical investigation of an outbreak of alveolitis and asthma in a car engine manufacturing plant
}

\author{
W Robertson, A S Robertson, C B S G Burge, V C Moore, M S Jaakkola, P A Dawkins, M Burd, \\ R Rawbone, I Gardner, M Kinoulty, B Crook, G S Evans, J Harris-Roberts, S Rice, P S Burge
}

Thorax 2007;62:981-990. doi: 10.1136/thx.2006.072199

See end of article for authors' affiliations

Correspondence to:

Wendy Robertson, Lecturer in Public Health, Warwick Medical School, University of Warwick, Coventry CV4 7AL, UK;

W.Robertson@warwick. ac.uk

Received 25 September 2006 Accepted 6 April 2007

Published Online First

15 May 2007

\begin{abstract}
Background: Exposure to metal working fluid (MWF) has been associated with outbreaks of extrinsic allergic alveolitis (EAA) in the USA, with bacterial contamination of MWF being a possible cause, but is uncommon in the UK. Twelve workers developed EAA in a car engine manufacturing plant in the UK, presenting clinically between December 2003 and May 2004. This paper reports the subsequent epidemiological investigation of the whole workforce. The study had three aims: (1) to measure the extent of the outbreak by identifying other workers who may have developed EAA or other work-related respiratory diseases; (2) to provide case detection so that those affected could be treated; and (3) to provide epidemiological data to identify the cause of the outbreak.

Methods: The outbreak was investigated in a three-phase cross-sectional survey of the workforce. In phase I a respiratory screening questionnaire was completed by $808 / 836$ workers $(96.7 \%$ ) in May 2004 . In phase II 481 employees with at least one respiratory symptom on screening and 50 asymptomatic controls were invited for investigation at the factory in June 2004. This included a questionnaire, spirometry and clinical opinion. 454/481 (94.4\%) responded and 48/50 (96\%) controls. Workers were identified who needed further investigation and serial measurements of peak expiratory flow (PEF). In phase III 162 employees were seen at the Birmingham Occupational Lung Disease clinic. 198 employees returned PEF records, including 141 of the 162 who attended for clinical investigation. Case definitions for diagnoses were agreed.

Results: 87 workers ( $10.4 \%$ of the workforce) met case definitions for occupational lung disease, comprising EAA $(n=19)$, occupational asthma $(n=74)$ and humidifier fever $(n=7) .12$ workers had more than one diagnosis. The peak onset of work-related breathlessness was Spring 2003. The proportion of workers affected was higher for those using MWF from a large sump (27.3\%) than for those working all over the manufacturing area $(7.9 \%)(O R=4.39, p<0.001)$. Two workers had positive specific provocation tests to the used but not the unused MWF solution.

Conclusions: Extensive investigation of the outbreak of EAA detected a large number of affected workers, not only with EAA but also occupational asthma. This is the largest reported outbreak in Europe. Mist from used MWF is the likely cause. In workplaces using MWF there is a need to carry out risk assessments, to monitor and maintain fluid quality, to control mist and to carry out respiratory health surveillance.
\end{abstract}

$M$ etal working fluids (MWF) have been recognised as causing work-related respiratory problems since the 1950s. Initial reports of respiratory effects due to the inhalation of oil mists were limited to lipoid pneumonia. ${ }^{1-3}$ Case reports of occupational asthma (OA) due to both clean and used MWF have been recorded. ${ }^{4}{ }^{5}$ Subsequent surveys of workers exposed to MWF have found respiratory symptoms, ${ }^{6-9}$ often with associated bronchial hyper-responsiveness, ${ }^{79}$ cross-shift changes in lung function ${ }^{10-12}$ or reduced lung function. ${ }^{13}$ Many of these surveys have been done in the automotive industries.

The first cases of alveolitis due to MWF were reported in the mid 1990s by Bernstein et al in the USA who described six cases of hypersensitivity pneumonitis (extrinsic allergic alveolitis, EAA).$^{14}$ Precipitating antibodies were found to a number of microbial isolates, the most common being Pseudomonas fluorescens. Further outbreaks in the USA have been reported, ${ }^{15-17}$ several in the automotive industry. ${ }^{14-16}$ Bacterial (particularly mycobacteria) or fungal contamination of MWF are thought to be the causes, but no specific agent has fulfilled the criteria for a specific cause..$^{16}$

MWF has been an uncommon cause of EAA in the UK with only one case being reported to SWORD, the UK national voluntary notification scheme, from 1995 to 2002. Twelve employees from a car engine manufacturing plant in England who presented to us between December 2003 and May 2004 were diagnosed as having EAA. Dawkins et al have presented the findings from this case series of 12 workers, which showed heterogeneous clinical, radiological and pathological findings, but all met the case definition for EAA. ${ }^{18}$ The factory machined engine parts from aluminium alloys or cast iron and assembled car engines. The machining process used MWF (oil water emulsions with chemical additives including biocides). During use the MWF became contaminated by lubricating and hydraulic oil (tramp oil). Some machines had their own MWF sumps, but most used one of four common sumps, the largest with a capacity of $>200000$ litres. Machined parts were washed with a mixture of water and detergent which was recirculated. Some washers produced inhalable aerosols.

In May 2004 we carried out an epidemiological investigation of the whole workforce which had three aims:

- To measure the extent of the outbreak by identifying other workers who may have developed EAA or other work-related respiratory diseases.

Abbreviations: EAA, extrinsic allergic alveolitis; $\mathrm{FEV}_{1}$, forced expiratory volume in $1 \mathrm{~s} ; \mathrm{FVC}$, forced vital capacity; HF, humidifier fever; MWF, metal working fluid; $\mathrm{OA}$, occupational asthma; PEF, peak expiratory flow 


\section{Table 1 Case definitions for work-related respiratory disease

\begin{tabular}{|c|c|}
\hline Disease & Criteria for case definitions \\
\hline $\begin{array}{l}\text { Extrinsic allergic } \\
\text { alveolitis (at least } \\
4 \text { of the } 7 \text { criteria } \\
\text { must be met) }\end{array}$ & $\begin{array}{l}\text { Onset of disease after December } 2002 \text { and: } \\
\text { (1) physician diagnosis of EAA (probable or definite); } \\
\text { (2) onset of at least two pulmonary symptoms (cough, } \\
\text { wheeze, chest tightness, shortness of breath) and one } \\
\text { systemic symptom (fever, weight loss); } \\
\text { (3) a history of symptoms improving regularly on days } \\
\text { away from work and deteriorating on return to work; } \\
\text { (4) Restrictive pattern on spirometry: FVC }<80 \% \\
\text { predicted and FEV }{ }_{1} / F V C>70 \% \text {; } \\
\text { (5) pulmonary carbon monoxide transfer factor }<80 \% \\
\text { predicted; } \\
\text { (6) chest radiograph or CT scan showing interstitial, } \\
\text { reticulonodular or mosaic pattern; } \\
\text { (7) biopsy evidence of non-caseating granulomas and/ } \\
\text { or lymphocytosis on bronchoalveolar lavage }\end{array}$ \\
\hline $\begin{array}{l}\text { Occupational } \\
\text { asthma }\end{array}$ & $\begin{array}{l}\text { Diagnostic peak expiratory flow record in } 2003-5 \text { (ie, } \\
\text { OASYS score } \geqslant 2.67 \text { and/or a mean day interpreted } \\
\text { difference between work and rest days of } \geqslant 16 \mathrm{l} / \mathrm{min})^{21}\end{array}$ \\
\hline Humidifier fever & $\begin{array}{l}\text { Onset of disease after December } 2002 \text { and a physician } \\
\text { diagnosis based on: } \\
\text { Recurrent symptoms of a flu-like illness worst on first day } \\
\text { of exposure after a break } \\
\text { No weight loss or radiological infiltrates } \\
\text { No long-term restrictive lung disease }\end{array}$ \\
\hline
\end{tabular}

EAA, extrinsic allergic alveolitis; $F E V_{1}$, forced expiratory volume in $1 \mathrm{~s}$; FVC, forced vital capacity.

- To provide case detection so that those affected could be treated.

- To provide epidemiological data to identify the cause of the outbreak so that appropriate remedial action could be taken; specifically, to examine the association of MWF quality and MWF usage with work-related respiratory disease.

This paper reports the results of the epidemiological investigation. A brief summary of the environmental investigation is given.

\section{METHODS \\ Clinical investigation}

A three-phase cross-sectional survey of the entire workforce was carried out to identify cases of respiratory disease. The payroll list from the Human Resources Department was used as the sample frame, which identified 832 current employees (33 subcontractors, 799 direct employees) and four index cases of alveolitis who were on sick leave, totalling 836 employees. Employees were assigned by the workplace to one of 57 operational codes which, in most cases, were closely linked to a specific work area.

\section{Phase I: Screening questionnaire}

A short respiratory screening questionnaire (11 questions on respiratory and nasal symptoms) was distributed to the 836 employees in May 2004. Workers were asked to report symptoms present in the previous 18 months. Non-responders were contacted twice more.

\section{Phase II: Factory-based assessment}

In June 2004 those workers with one or more respiratory symptoms and/or weight loss on the screening questionnaire were invited for further assessment. A control group of 50 asymptomatic workers was selected randomly from the 180 employees who declared no symptoms on the respiratory screening questionnaire. The selection of the controls was done with a random number table using the last three digits of their payroll number.

The assessment consisted of:

\section{Questionnaire}

A detailed self-completed questionnaire asked about demographic information, job history and clinical information (available on www.occupationalasthma.com/resources/outbreak respiratory survey.doc). The questionnaire inquired whether symptoms were "better", the "same" or "worse" on "days away from work" and "holidays". Symptoms were classified as work-related if they improved on days off or on holiday. The month and year of first onset of each symptom was recorded.

\section{Spirometry}

Spirometry was measured on a wedge bellows spirometer (Vitalograph) according to ATS/ERS standards using ECCS predicted values. ${ }^{19}$

\section{Clinical opinion}

Participants were seen by an experienced occupational respiratory physician; those with possible OA were asked to record serial measurements of peak expiratory flow (PEF), with subsequent clinical investigation depending on the result. Those with possible alveolitis or humidifier fever (HF) were offered full clinical investigation (phase III).

\section{Phlebotomy}

$20 \mathrm{ml}$ blood was taken into two plain bottles with the serum frozen for later analysis for precipitins at the Health and Safety Laboratory (HSL), Sheffield, UK. The results are reported separately by the HSL. ${ }^{20}$

\section{Phase III: Full clinical assessment \\ Peak flow records}

Standard instructions for PEF records included 2-hourly measurements from waking to bedtime on days at work and days away from work for a total of 4 weeks. ${ }^{21}$ Records were analysed using Oasys-2 computing program which plots and analyses serial measurements of PEF for occupational effect. Oasys-2 works by discriminant analysis, scoring "complexes" that are comprised of a work-rest-work pattern or a rest-workrest pattern. Validation studies show that Oasys-2 has a sensitivity of $75 \%$ and a specificity of $94 \%$ for detecting OA. ${ }^{22}$ An Oasys score of $\geqslant 2.67$ and/or a mean day interpreted difference between work and rest days of $\geqslant 16 \mathrm{l} / \mathrm{min}$ were defined as showing OA. ${ }^{21} 22$

\section{Clinical investigation}

Workers selected in the previous phase were seen between November 2004 and March 2005 by two occupational respiratory physicians. Investigations included lung function tests, including transfer factor (single breath Jaeger Masterscreen system 2), chest radiograph and methacholine challenge (Yan method) for bronchial hyper-reactivity. Skin prick tests were performed for common environmental allergens with saline negative control, histamine positive control plus allergens house dust, house dust mite, feathers, horse hair, cat dander, dog dander, mixed grasses, mixed tree pollens, plantain pollen, egg, milk, fish, wheat pollen, Cladosporium, Alternaria alternaria, Aspergillus fumigatus, Penicillium sp and Merulius lacrymans. Atopy was defined as at least one positive weal ( $\geqslant 3 \mathrm{~mm}$ above saline control) to a common inhalable allergen. Lung volumes (helium dilution), high-resolution CT (HRCT) scans and bronchoscopy were performed if indicated. A clinical diagnosis was made on the results of investigations and history. 


\section{Case definitions}

Case definitions for work-related respiratory diseases were agreed (table 1) and applied to workers that had undergone further clinical investigations. Case definitions for EAA were adapted from Fox et al. ${ }^{16}$ OA required a diagnostic PEF record $^{21} 22$ and HF was based on history (table 1). We defined January 2003 as the onset date for the outbreak based on the presentation of the 12 index cases of EAA.

\section{Specific challenge tests}

Two individuals, one with a pre-test diagnosis of EAA and one with $\mathrm{OA}$ and resolved HF, had occupational-type bronchial provocation testing 6 months after removal from exposure. Challenges to unused MWF used at the factory (a mixture of two products and water containing a number of chemicals including tolytriazole, ethanolamines, tall oil and boric acid) and used MWF taken from the largest common sump were performed on separate days. Initially, exposures were by a Pari Pot nebuliser with the aerosol directed generally into the challenge chamber for sequential periods of 10, 20 then $40 \mathrm{~min}$ (total exposure $70 \mathrm{~min}$ ). Rest breaks occurred between challenges and any significant response would have terminated the challenge. Further challenges were made with the aerosol inhaled directly from the nebuliser using a mouthpiece for up to 17 min (2, 5 and 10 min with breaks). Spirometric parameters were measured pre-challenge and regularly for at least $11 \mathrm{~h}$ post-challenge. A fall in forced expiratory volume in $1 \mathrm{~s}\left(\mathrm{FEV}_{1}\right)$ of $>15 \%$ from baseline was taken as a positive test.

\section{Environmental investigation}

Over the period of the outbreak, area and personal measurements of MWF in air were conducted using Health and Safety Executive (HSE) standard methodology, estimating total aerosol by extrapolating from the boron content of MWF. ${ }^{23}$ Personal sampling was done over a 4-5-h period. Common sumps were monitored for $\mathrm{pH}$, concentration, tramp oil, bacteria and fungi. Smaller sumps were monitored for concentration and pH. From November 2003, sump samples were analysed for bacteria and fungi.

\section{Ethical approval}

Ethical approval was not obtained as this report is the result of surveillance and the investigation of surveillance failures required by a legally binding improvement notice from the Health and Safety Executive. The surveillance was approved by both worker and management representatives.

\section{Analysis of data}

The onset (month and year) of work-related breathlessness reported in the phase II questionnaire was plotted and related to the concentration of tramp oil in MWF. Gender, ethnicity, smoking and use of MWF were then compared for the affected and non-affected populations using a $\chi^{2}$ test (with Yates

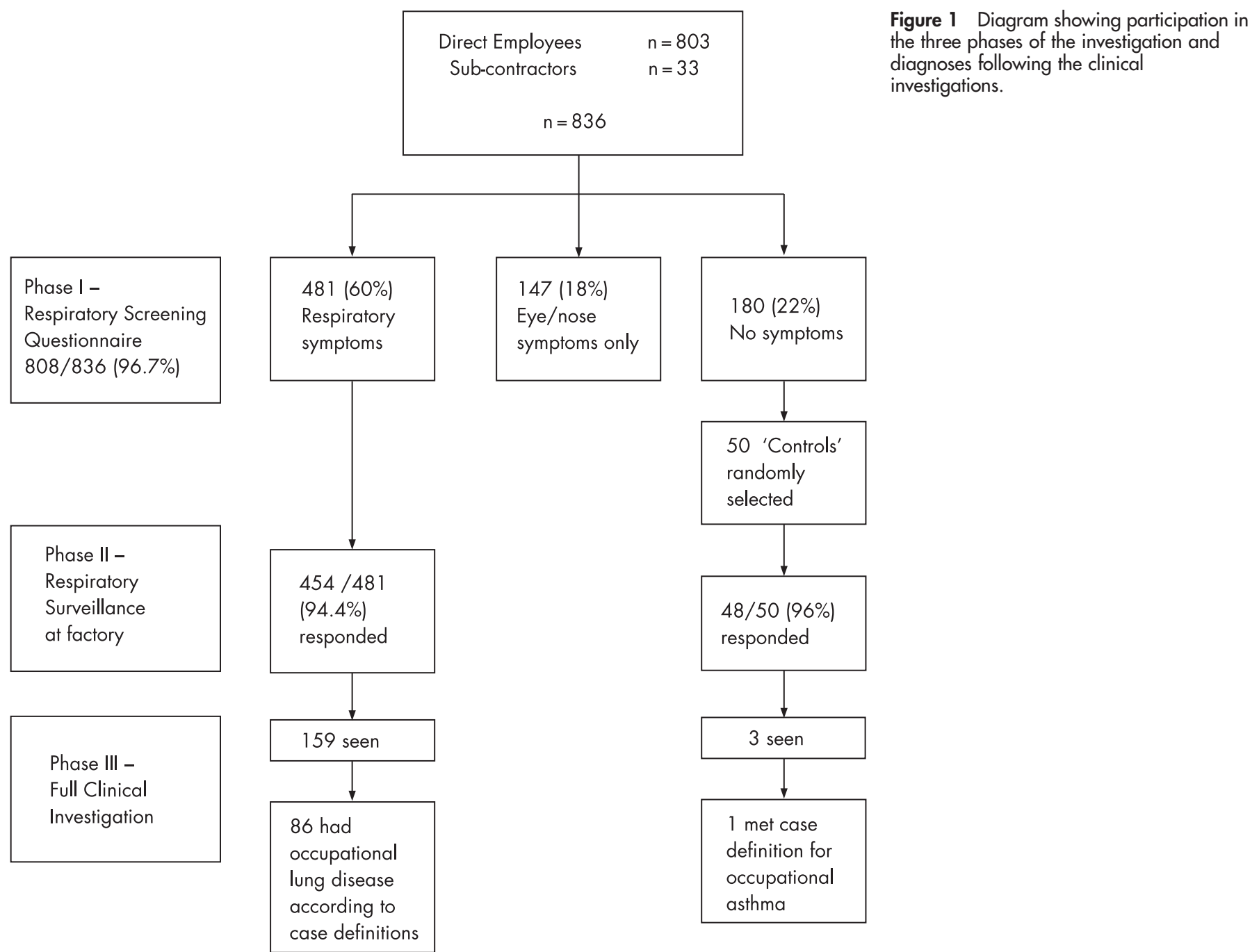

Figure 1 Diagram showing participation in (n) clinical investigations. 
Table 2 Characteristics of employees with respiratory symptoms, the asymptomatic control group who completed phase II and those meeting the case definitions for extrinsic allergic alveolitis (EAA) and occupational asthma (OA) in phase III

\begin{tabular}{|c|c|c|c|c|c|c|c|}
\hline & & $\begin{array}{l}\text { (1) Respiratory } \\
\text { symptoms on } \\
\text { screening } \\
\text { questionnaire } \\
\text { ( } \mathrm{n}=454 \text { ) }\end{array}$ & $\begin{array}{l}\text { (2) Met case } \\
\text { definition } \\
\text { for EAA } \\
(n=19)^{*}\end{array}$ & $\begin{array}{l}\text { (3) Met case } \\
\text { definition } \\
\text { for } O A \\
(n=66) \dagger\end{array}$ & $\begin{array}{l}\text { (4) Controls } \\
(n=47)\end{array}$ & $\begin{array}{l}\text { Statistical } \\
\text { difference } \\
(1 \text { vs } 4) \pm\end{array}$ & $\begin{array}{l}\text { Statistical } \\
\text { difference } \\
\text { (2 vs } 3 \text { vs } 4 \text { )§ }\end{array}$ \\
\hline Age (years) & Mean (SD) & $44.7(8.6)$ & $47.5(7.9)$ & $43.4(7.6)$ & $43.6(10.5)$ & $p=0.417$ & $p=0.176$ \\
\hline \multicolumn{8}{|l|}{ Gender } \\
\hline Men & $n(\%)$ & $419(92.2 \%)$ & $17(89.5 \%)$ & $59(89.4 \%)$ & $43(91.5 \%)$ & $p=1.000$ & Not done \\
\hline Women & & $35(7.8 \%)$ & $2(10.5 \%)$ & $7(10.6 \%)$ & $4(8.5 \%)$ & & \\
\hline \multicolumn{8}{|l|}{ Ethnicity } \\
\hline Caucasian & $n(\%)$ & $396(87.2 \%)$ & $18(94.7 \%)$ & $53(80.3 \%)$ & $44(93.6 \%)$ & $p=0.298$ & $p=0.064$ \\
\hline Non-Caucasian & & $58(12.8 \%)$ & $1(5.3 \%)$ & $13(19.7 \%)$ & $3(6.4 \%)$ & & \\
\hline \multicolumn{8}{|l|}{ Smoking } \\
\hline Current & $\mathrm{n}(\%)$ & $125(28 \%)$ & $3(15.8 \%)$ & $15(22.7 \%)$ & $6(14.3 \%)$ & $\begin{array}{l}p=0.086 \\
\text { (current vs others) }\end{array}$ & $\begin{array}{l}p=0.513 \\
\text { (current vs others) }\end{array}$ \\
\hline Ex & & $127(28 \%)$ & $7(36.8 \%)$ & $18(27.3 \%)$ & $13(31.0 \%)$ & & \\
\hline Never & & $197(44 \%)$ & $9(47.4 \%)$ & $33(50 \%)$ & $23(54.7 \%)$ & & \\
\hline $\mathrm{FEV}_{1}(\mathrm{I})$ & Mean (SD) & $3.52(0.76)$ & $2.90(0.66)$ & $3.45(0.69)$ & $3.91(0.76)$ & & \\
\hline $\mathrm{FEV}_{1}(\%$ predicted) & Mean (SD) & $96.8(15.8)$ & $83.4(15.9)$ & $94.9(14.9)$ & $102.8(14.9)$ & $p=0.012$ & $p<0.001$ \\
\hline FVC (I) & Mean (SD) & $4.50(0.93)$ & $3.58(0.74)$ & $4.40(0.86)$ & $4.99(0.98)$ & & \\
\hline FVC (\% predicted) & Mean (SD) & $103.5(15.7)$ & $85.1(15.9)$ & $101.4(14.9)$ & $110.0(17.1)$ & $p=0.008$ & $p<0.001$ \\
\hline \multicolumn{8}{|c|}{ Works mostly in manufacturing } \\
\hline Yes & $n(\%)$ & $368(81 \%)$ & $19(100 \%)$ & $64(97 \%)$ & $28(60.9 \%)$ & $p=0.002$ & $p<0.001$ \\
\hline No & $n(\%)$ & $86(19 \%)$ & $0(0 \%)$ & $2(3 \%)$ & $18(39.1 \%)$ & & \\
\hline \multicolumn{8}{|c|}{$\begin{array}{l}\text { Ever worked on machine with } \\
\text { MWF }\end{array}$} \\
\hline Yes & $n(\%)$ & $270(60 \%)$ & $14(73.7 \%)$ & $43(65.2 \%)$ & $22(46.8 \%)$ & $p=0.111$ & $p=0.06$ \\
\hline No & $n(\%)$ & $180(40 \%)$ & $5(26.3 \%)$ & $23(34.8 \%)$ & $25(53.2 \%)$ & & \\
\hline $\begin{array}{l}\text { Duration of employment at } \\
\text { factory (years) }\end{array}$ & Median (IQR) & $10.5(5-15)$ & $9(4-12)$ & $12(6-15)$ & $9(4-15)$ & $p=0.403$ & $p=0.306$ \\
\hline
\end{tabular}

$\mathrm{FEV}_{1}$, forced expiratory volume in $1 \mathrm{~s} ; \mathrm{FVC}$, forced vital capacity; MWF, metal working fluid.

*Eight also had OA.

†Excludes eight with EAA.

$\ddagger$ Analysis by $t$ test for age, $\mathrm{FEV}_{1}$ and $\mathrm{FVC}$; Mann-Whitney $\mathrm{U}$ test for duration of employment.

\$Analysis by one-way ANOVA for age, $\mathrm{FEV}_{1}$ and FVC; Kruskal-Wallis test for duration of employment.

$\ddagger$, SCategorical data analysed by $\chi^{2}$ test.

continuity correction for $2 \times 2$ tables). Age and lung function were compared using a $t$ test and one-way analysis of variance. Duration of employment was not normally distributed so differences were analysed by the Mann-Whitney $U$ and Kruskal-Wallis tests.

The prevalence of work-related respiratory disease (EAA, OA and HF) was calculated for the 57 operational codes using the number working in each operational code as the denominator. Fisher's exact test was used to compare the proportion with disease in a specific work location with the proportion of disease in the rest of the workforce. Each code was also assigned to one of the following five groups: (1) machining using MWF from a large common sump; (2) machining using MWF from a single or local sump; (3) assembly and other manufacturing: working in the manufacturing area but not using MWF directly (predominantly assembly jobs); (4) working all over the plant in the manufacturing area; and (5) working outside the main plant or in the office block.

Logistic regression was used to see if the occurrence of disease differed across these five location groups and an odds ratio was obtained using the fourth group (working all over the plant) as the reference category. There was not enough disease in the fifth group (working outside the plant or in offices) for this to be used as the reference group. Statistical analysis was performed using SPSS Version 12.

\section{RESULTS}

The workers investigated in the three phases of the study and their diagnoses are shown in fig 1 .

\section{Phase I: Screening questionnaire}

The screening questionnaire was completed by 808/836 (96.7\%) workers; $481(60 \%)$ had at least one respiratory symptom, 147
( $18 \%)$ had eye or nasal symptoms only and 180 (22\%) were asymptomatic.

\section{Phase II: Factory-based assessment}

Four hundred and fifty-four $(94.4 \%)$ of the 481 workers with at least one respiratory symptom on the screening questionnaire and 48/50 (96\%) asymptomatic "controls" attended phase II. Table 2 shows their demographic characteristics. Compared with asymptomatic controls, those with respiratory symptoms had lower lung function, more worked in manufacturing and more smoked.

The detailed questionnaire showed that 146 employees had at least grade I MRC breathlessness, which was better on days away from work and/or on holiday ("work-related") (table 3). Of these, 54/127 who gave a year when they first developed breathlessness had an onset in 2003 or later. Seventy workers defined the month when they first developed breathlessness, showing peaks in March and June 2003 (fig 2). The prevalence of symptoms was $9.3 \%$ consistent with occupational bronchitis, $18.6 \%$ with work-related asthma and $2.1 \%$ with HF (table 3 ).

\section{Phase III: Full clinical assessment}

One hundred and seventy-three employees were identified for full clinical investigation as a result of either the factory assessment or the results of their PEF chart. Of the 173, 162 attended, 7 declined and 4 failed to attend. In total, 198 workers completed PEF charts for analysis; this included 141 of the 162 who attended for clinical investigation and a further 57 employees who were not seen (as their results were negative). Four controls were among those who completed PEF records. Based on clinical opinion, 102 workers were diagnosed with probable or definite occupational lung disease including 24 with EAA, 88 with OA and 7 with HF (some with more than 


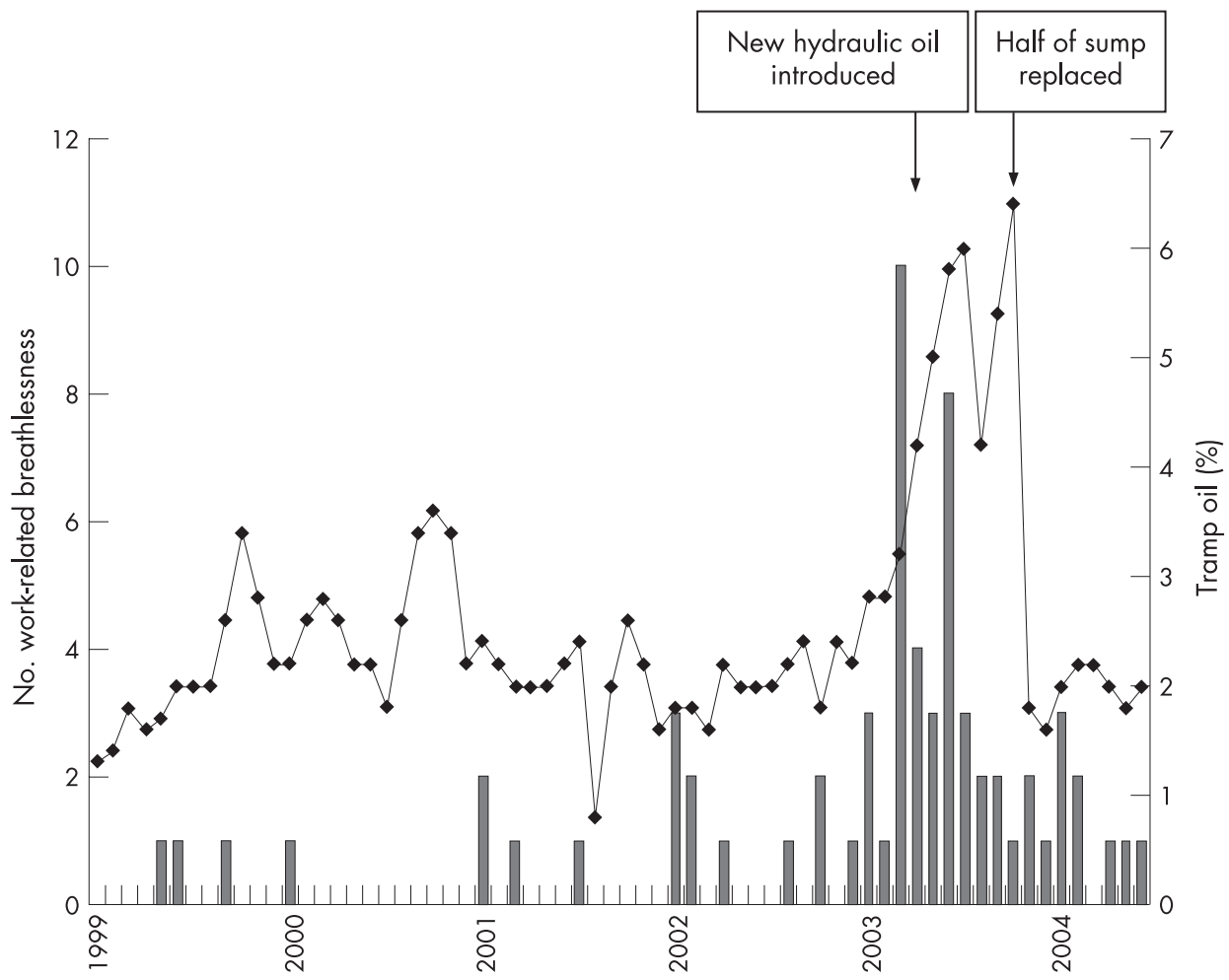

Figure 2 Onset of work-related breathlessness from phase II questionnaire (bars) in relation to the peak monthly tramp oil levels in metal working fluid (line).

one diagnosis). Additionally, 15 workers were diagnosed with occupational bronchitis (defined by cough productive of sputum which was better away from exposure). There were also single cases of bronchopulmonary aspergillosis (diagnosed immunologically), lipoid pneumonitis and Langerhans' cell histiocytosis (both diagnosed from histology).
Phase III: Numbers meeting the case definitions

Nineteen workers met the case definition for EAA (at least four of the seven criteria; table 4). Sixteen of these had the onset of symptoms after January 2003 (table 4). Seventy-four of the 198 employees who returned PEF records had a recording which met the case definition for OA (table 4). Half of these had first

Table 3 Self-reported work-related respiratory symptoms at the factory assessment (phase II)

\begin{tabular}{|c|c|c|c|c|c|c|}
\hline & \multicolumn{3}{|c|}{ Respiratory symptoms on screening questionnaire $(n=454)^{*}$} & \multicolumn{3}{|c|}{ Controls: asymptomatic on screening questionnaire $(n=48)$} \\
\hline & $\begin{array}{l}\text { Work-related } \\
\text { n (\%) }\end{array}$ & $\begin{array}{l}\text { Not work-related } \\
\text { n (\%) }\end{array}$ & $\begin{array}{l}\text { Total } \\
\mathrm{n}(\%)\end{array}$ & $\begin{array}{l}\text { Work-related } \\
\text { n (\%) }\end{array}$ & $\begin{array}{l}\text { Not work-related } \\
\text { n }(\%)\end{array}$ & $\begin{array}{l}\text { Total } \\
\text { n (\%) }\end{array}$ \\
\hline \multicolumn{7}{|l|}{ MRC Breathlessness } \\
\hline $\begin{array}{l}\text { MRC1: Troubled by shortness of breath } \\
\text { when hurrying on level ground or walking } \\
\text { up a slight hill }\end{array}$ & $146(17.5 \%)$ & $77(9.2 \%)$ & $223(26.7 \%)$ & $2(4 \%)$ & - & $2(4 \%)$ \\
\hline $\begin{array}{l}\text { MRC2: Short of breath walking with other } \\
\text { people of own age and sex on level ground }\end{array}$ & $89(10.6 \%)$ & $41(4.9 \%)$ & $130(15.5 \%)$ & $1(2 \%)$ & - & $1(2 \%)$ \\
\hline $\begin{array}{l}\text { MRC3: Had to stop for breath when walking } \\
\text { at own pace on level ground }\end{array}$ & $41(4.9 \%)$ & $17(2 \%)$ & $58(6.9 \%)$ & - & - & - \\
\hline MRC4: Short of breath washing or dressing & $16(1.9 \%)$ & $7(0.8 \%)$ & $23(2.7 \%)$ & - & - & - \\
\hline \multicolumn{7}{|l|}{ MRC Chronic Bronchitis } \\
\hline $\begin{array}{l}\text { MRC chronic bronchitis: sputum production } \\
\text { for } 3 \text { months each year for } 2 \text { years or more }\end{array}$ & $78(9.3 \%)$ & $53(6.3 \%)$ & $131(15.6 \%)$ & - & - & - \\
\hline \multicolumn{7}{|l|}{ Asthma type symptoms } \\
\hline $\begin{array}{l}\text { In last } 12 \text { months has your chest ever felt } \\
\text { tight or your breathing become difficult? }\end{array}$ & $156(18.6 \%)$ & $100(12.0 \%)$ & $256(30.6 \%)$ & - & $2(4 \%)$ & $2(4 \%)$ \\
\hline $\begin{array}{l}\text { In the past } 12 \text { months have you had } \\
\text { wheezing or whistling in your chest? }\end{array}$ & $122(14.6 \%)$ & $105(12.6 \%)$ & $227(27.2 \%)$ & - & $2(4 \%)$ & $2(4 \%)$ \\
\hline \multicolumn{7}{|l|}{ Humidifier fever type symptoms } \\
\hline $\begin{array}{l}\text { In the past } 12 \text { months have you suffered } \\
\text { recurrent flu-like symptoms on five or more } \\
\text { occasions? (Work-relatedness was defined } \\
\text { as symptoms at the beginning of the working } \\
\text { week and/or being more frequent/severe on } \\
\text { returning to work after a weekend or holiday) }\end{array}$ & $18(2.1 \%)$ & $13(1.6 \%)$ & $31(3.7 \%)$ & - & - & - \\
\hline
\end{tabular}

*Note that the total workforce of 836 used as denominator. 
Table 4 Numbers with work-related respiratory disease according to case definitions for extrinsic allergic alveolitis (EAA), occupational asthma and humidifier fever with year of onset of symptoms from phase III

\begin{tabular}{|c|c|c|c|}
\hline \multirow[b]{2}{*}{ Disease } & \multicolumn{3}{|c|}{ Met case definition } \\
\hline & $\begin{array}{l}\text { Symptoms } \\
\text { before } 2003\end{array}$ & $\begin{array}{l}\text { Symptoms } 2003 \\
\text { and onwards }\end{array}$ & Total \\
\hline Occupational asthma & 37 & 37 & 74 \\
\hline Humidifier fever & 1 & 6 & 7 \\
\hline EAA meeting at least 4 out of 7 Fox criteria & 3 & 16 & 19 \\
\hline $\begin{array}{l}\text { Numbers meeting each of the Fox criteria for } \text { EAA }^{16} \\
\text { (1) Physician diagnosis of EAA (probable or definite) }(n=19)\end{array}$ & 3 & 16 & 19 \\
\hline $\begin{array}{l}\text { (2) Onset of at least } 2 \text { pulmonary symptoms (cough, wheeze, } \\
\text { chest tightness, shortness of breath) and one systemic } \\
\text { symptom (fever, weight loss) }(n=19)\end{array}$ & 3 & 14 & 17 \\
\hline $\begin{array}{l}\text { (3) A history of symptoms improving regularly on days away } \\
\text { from work and deteriorating on return to work }(n=19)\end{array}$ & 3 & 16 & 19 \\
\hline $\begin{array}{l}\text { (4) Restrictive pattern on spirometry: FVC }<80 \% \text { predicted } \\
\text { and } \mathrm{FEV} / \mathrm{FVC}>70 \%(n=19)\end{array}$ & 1 & 3 & 4 \\
\hline (5) Pulmonary transfer factor $<80 \%$ predicted $(n=19)$ & 2 & 12 & 14 \\
\hline $\begin{array}{l}\text { (6) Chest radiograph or CT scan showing interstitial, } \\
\text { reticulonodular or mosaic pattern }(n=19)\end{array}$ & 2 & 13 & 15 \\
\hline $\begin{array}{l}\text { (7) Biopsy evidence of non-caseating granulomas and/or } \\
\text { lymphocytosis on bronchoalveolar lavage }(n=16)\end{array}$ & 1 & 8 & 9 \\
\hline
\end{tabular}

onset of asthma-type symptoms since January 2003. Eight of the 74 also met the EAA case definition. Taking into account the overlap of disease, 87 employees (10.4\% of the workforce) met case definitions for one or more of EAA, OA and HF (fig 3 ). Hereafter the analysis will refer to these 87 workers.

Unexpectedly, a "control" who was asymptomatic on the screening questionnaire was diagnosed as having OA, supported by a diagnostic PEF record (fig 1). During clinical investigation he denied many symptoms. His spirometric parameters were abnormal ( $\mathrm{FEV}_{1} 68 \%$, FVC $74 \%$ predicted).

Workers who met the case definition for EAA and OA were compared with the asymptomatic controls (table 2). Those with EAA had restrictive disease with the lowest $\mathrm{FEV}_{1}$ and FVC, those with OA had obstructive spirometry (on average), and the controls had values above predicted as would be expected for a healthy worker population. There was no difference in the smoking history, demographic characteristics or the length of exposure when defined by duration of employment in the three groups. However, almost all of those with OA (97\%) and all with EAA (100\%) worked in the manufacturing areas, significantly higher than the proportion in the control group $(61 \%)$. Also, a higher proportion of those with EAA and OA had worked directly with MWF compared with the controls.

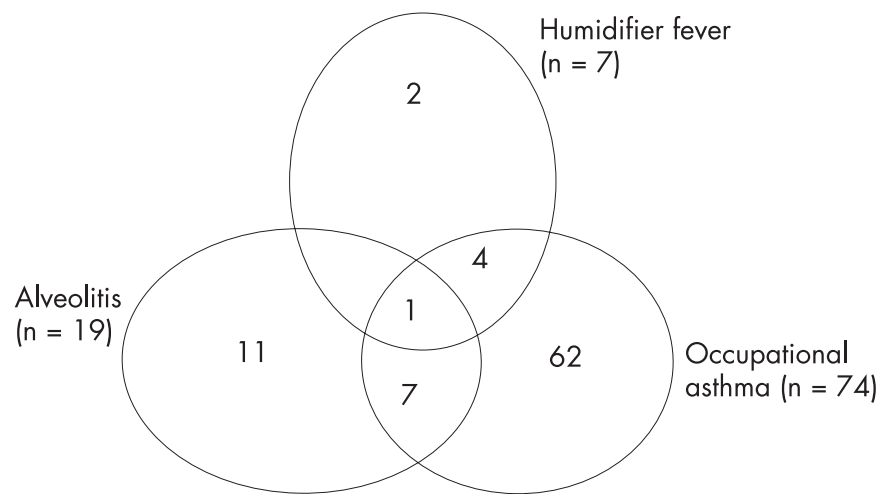

Figure 3 Case-defined work-related respiratory disease $(n=87)$ showing overlap of disease at phase III.
Skin tests for atopic status were performed on 13/19 workers with EAA and 61/66 workers with OA; 3/13 (23\%) with EAA and $33 / 61(54 \%)$ with OA were atopic, showing the risk of OA to be associated with atopy.

\section{Work location of the 87 workers with work-related respiratory disease (phase III)}

The 87 workers with disease were distributed across 22 work locations in the factory (fig 4), with no workers with disease in 35 other work locations (as defined by their operational codes). Geographically, the cases of disease were clustered at the northern end of the factory. The work location with the highest number of cases was an engine assembly area (Assembly 1), but this also had the largest number of employees. As the numbers working in each location varies, the prevalence of disease is shown in fig 5. Four work locations all involved in machining (Machining 1, 2, 3 and 5) had a significantly higher rate of disease compared with the rest of the factory (fig 5). These four work locations were all in the northern half of the factory served directly by the largest common MWF sump (200 000 litres) or directly adjacent to it. A map of the factory showing the prevalence of disease for the work locations together with the location of the four main sumps and two washers shown to generate mist (Map l) is given in the online supplement available at http://thorax.bmj.com/supplemental.

Table 5 shows the distribution of cases across the five work location groups (see Map 2 in the online supplement available at http://thorax.bmj.com/supplemental for the location of these five areas within the factory). Working in machining using MWF from the largest common sump was associated with an increased risk of having disease of more than four times $(27.3 \%)$ compared with workers who worked all over the manufacturing area (7.9\%) (odds ratio (OR) 4.39, 95\% CI 2.00 to 9.60). Further analysis by type of disease showed that machining using MWF from the large sump significantly increased the odds of developing OA (OR 4.36, 95\% CI 1.69 to 11.24); for EAA the OR was increased but this was not statistically significant (OR 2.62,95\% CI 0.73 to 9.38).

\section{Challenge results}

Of the two workers challenged, the worker with alveolitis had a late reaction to used MWF with a $14.6 \%$ fall in $\mathrm{FEV}_{1}$ following 


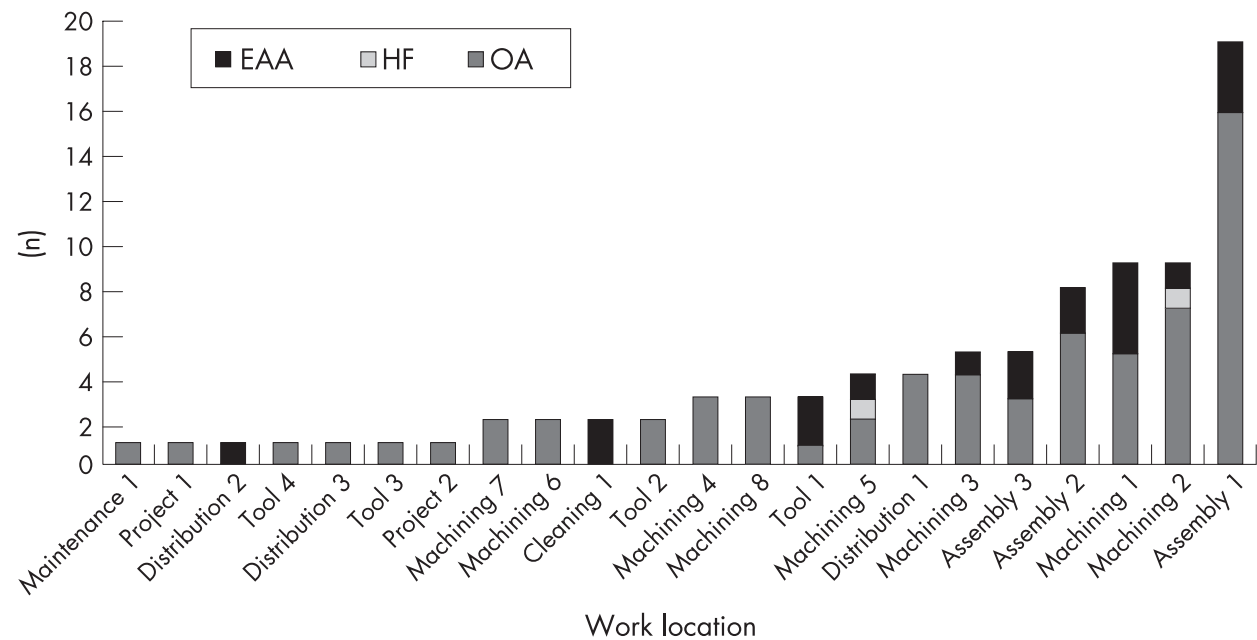

Figure 4 Work location of 87 workers with work-related respiratory disease. EAA, extrinsic allergic alveolitis; $O A$, occupational asthma; HF, humidifier fever.

indirect exposure and a $22 \%$ fall after direct exposure, with $<1 \%$ change following unused MWF exposure. He had normal methacholine reactivity throughout. The worker with OA had a borderline reaction to the indirect exposure (immediate $13.7 \%$, late $11.2 \%$ with a lower $\mathrm{FEV}_{1}$ the following morning) and a significant dual asthmatic reaction with direct exposure (immediate 21.7\%, late 13\%; fig 6). His methacholine reactivity deteriorated from $2400 \mu \mathrm{g}$ (normal $>2000 \mu \mathrm{g}$ ) before the challenge to $300 \mu \mathrm{g}$ the day after the positive challenge.

\section{Environmental results}

Results of air monitoring between May 2002 and October 2003 showed that concentrations of MWF in air were generally below the then HSE guidance value of $1 \mathrm{mg} / \mathrm{m}^{3} .^{23}$ In October 2003 the levels of mineral oil mist in air were between 1 and $4 \mathrm{mg} / \mathrm{m}^{3}$ with an average concentration of just above $1 \mathrm{mg} / \mathrm{m}^{3}$, also generally below the exposure guidance value of $3 \mathrm{mg} / \mathrm{m}^{3}{ }^{24}$ Personal samples of mineral oil mist taken at the same time indicated exposures of $1-1.7 \mathrm{mg} / \mathrm{m}^{3}$, with an average exposure of $1.3 \mathrm{mg} / \mathrm{m}^{3}$

Samples of MWF taken from the largest common sump in August 2004 showed no bacterial, mycobacterial or fungal growth, with no increased endotoxin levels. DNA extraction identified Acinetobacter spp and Ochrobacter anthropi, but no
Mycobacterium spp. Acinetobacter spp and Ochrobacter anthropi were grown from washing machines. ${ }^{20}$

Factory records showed a steep rise in tramp oil in the MWF in the large communal sump around April 2003, just after the hydraulic oil used in machines was changed (fig 2). A complicating factor was the highest number of workers reported onset of breathlessness in March 2003, just before the tramp oil increased.

\section{DISCUSSION}

The current investigation of employees in a car manufacturing plant in the UK detected 19 workers with EAA according to a strict case definition. During the investigation we also uncovered a large unknown outbreak of OA, with 74 workers diagnosed on the basis of serial peak flow records which are both reasonably sensitive and very specific for identifying patients with OA. ${ }^{2122}$ A total of 87 workers met case definitions for OA and/or EAA and/or HF, an overall prevalence in the workforce of $10 \%$. Half of the workers with OA had symptoms before 2003 (the date for new onset was defined as January 2003 or later based on the 12 index cases of EAA), suggesting that the outbreak of OA may have begun earlier than the outbreak of EAA.

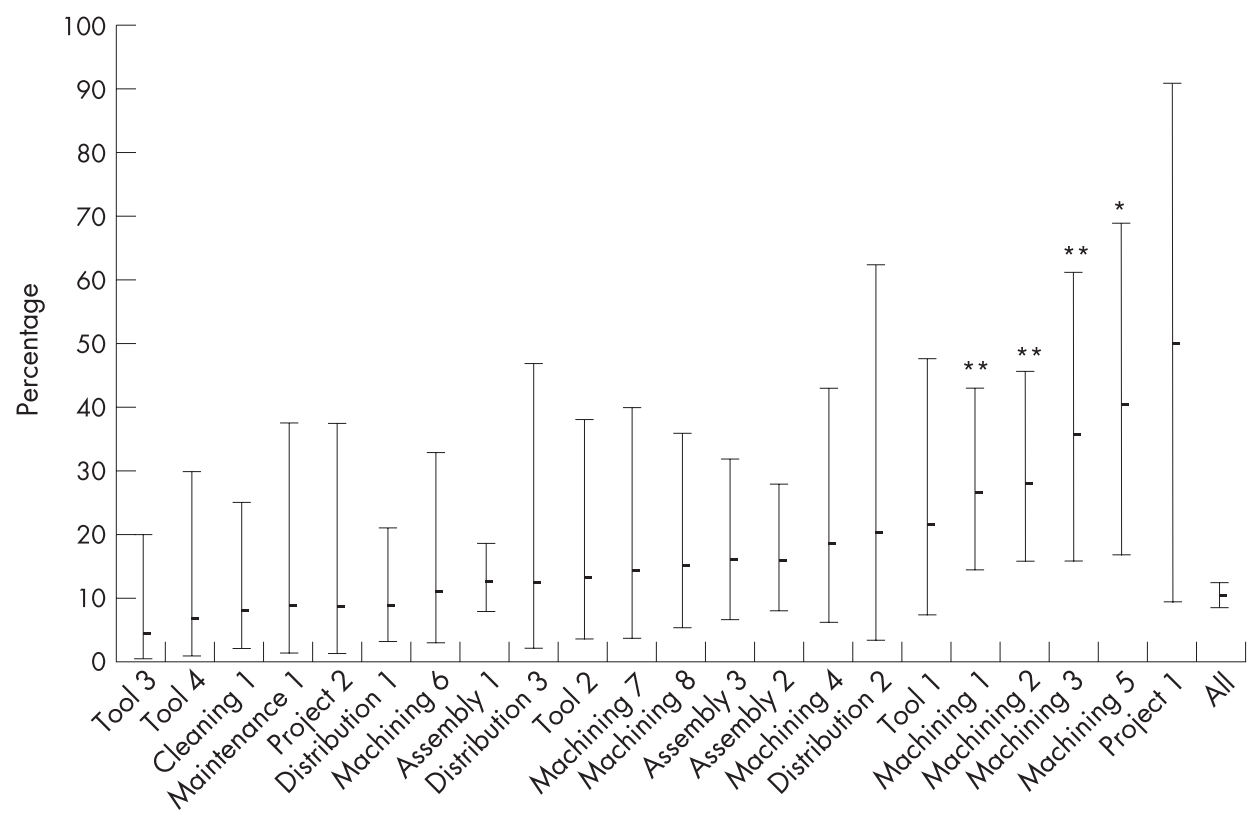

Figure 5 Percentage (with 95\% confidence intervals) of workers with work-related respiratory disease by work location; ${ }^{*} p<0.05,{ }^{* *} p<0.01$ work location higher than rest of workforce. 
Table 5 Percentage of workers with work-related respiratory disease (meeting the case definition) by grouped work location together with odds ratio (OR) of disease across work locations (phase III)*

\begin{tabular}{|c|c|c|c|c|c|c|c|}
\hline \multirow[b]{2}{*}{ Work location } & \multirow{2}{*}{$\begin{array}{l}\text { Total } \\
\text { population } \\
\text { (n) }\end{array}$} & \multicolumn{2}{|c|}{$\begin{array}{l}\text { Met case definition for EAA, OA } \\
\text { and/or HF }\end{array}$} & \multicolumn{2}{|c|}{$\begin{array}{l}\text { Met case definition for EAA } \\
\text { (8 also had OA) }\end{array}$} & \multicolumn{2}{|c|}{ Met case definition for $\mathrm{OA}$} \\
\hline & & n (\%) & $\begin{array}{l}\text { OR }(95 \% \text { Cl) vs } \\
\text { "works all over" }\end{array}$ & n (\%) & $\begin{array}{l}\text { OR }(95 \% \mathrm{Cl}) \text { vs } \\
\text { "works all over" }\end{array}$ & n (\%) & $\begin{array}{l}\text { OR }(95 \% \mathrm{Cl}) \text { vs } \\
\text { "works all over" }\end{array}$ \\
\hline $\begin{array}{l}\text { (1) Machining using } \\
\text { large MWF sump }\end{array}$ & 66 & $18(27.3 \%)$ & $\begin{array}{l}4.39(2.00 \text { to } 9.60) \\
p<0.001\end{array}$ & $5(7.6 \%)$ & $\begin{array}{l}2.62(0.73 \text { to } 9.38) \\
p=0.138\end{array}$ & $12(18.2 \%)$ & $\begin{array}{l}4.36(1.69 \text { to } 11.24) \\
p=0.002\end{array}$ \\
\hline $\begin{array}{l}\text { (2) Machining using } \\
\text { single/local MWF } \\
\text { sumps }\end{array}$ & 150 & $19(12.7 \%)$ & $\begin{array}{l}1.70(0.81 \text { to } 3.57) \\
p=0.164\end{array}$ & $2(1.3 \%)$ & $\begin{array}{l}0.43(0.08 \text { to } 2.26) \\
p=0.321\end{array}$ & $16(10.7 \%)$ & $\begin{array}{l}2.34(0.97 \text { to } 5.65) \\
p=0.058\end{array}$ \\
\hline $\begin{array}{l}\text { (3) Assembly and } \\
\text { other manufacturing }\end{array}$ & 320 & $36(11.3 \%)$ & $\begin{array}{l}1.48(0.76 \text { to } 2.88) \\
p=0.246\end{array}$ & $7(2.2 \%)$ & $\begin{array}{l}0.72(0.22 \text { to } 2.29) \\
p=0.573\end{array}$ & $29(9.1 \%)$ & $\begin{array}{l}1.96(0.87 \text { to } 4.38) \\
p=0.103\end{array}$ \\
\hline $\begin{array}{l}\text { (4) Works all over } \\
\text { plant }\end{array}$ & 165 & $13(7.9 \%)$ & 1 & $5(3.0 \%)$ & 1 & $8(4.8 \%)$ & 1 \\
\hline $\begin{array}{l}\text { (5) Outside/office } \\
\text { building }\end{array}$ & 135 & $1(0.7 \%)$ & & $0(0 \%)$ & & $1(0.7 \%)$ & \\
\hline Total & 836 & 87 (10.4\%) & & 19 (2.3\%) & & 66 (7.9\%) & \\
\hline
\end{tabular}

* Denominators are total population in each work location.

We also identified workers with HF and work-related chronic bronchitis, as well as single cases of histologically confirmed lipoid pneumonitis and Langerhans' cell histiocytosis and immunologically confirmed bronchopulmonary aspergillosis. The variety of different presentations of work-related respiratory disease related to exposure to MWF in the current study is consistent with other outbreaks of EAA in the USA. Zacharisen et al reported cases of EAA, asthma and bronchitis in a car engine manufacturing plant. ${ }^{26}$ Hodgson et al found that many workers with EAA also had asthma, and there was at least one case of usual interstitial pneumonia and a case of sarcoidosis at the plant which produced titanium and steel parts for the aerospace industry. ${ }^{17}$ Similarly, in the present investigation 8 of the 19 workers who met the case definition for EAA also had peak flow variability consistent with the case definition for OA. EAA can produce findings of airways obstruction on spirometry, possibly due to associated bronchiolitis. It is conceivable that such airways obstruction would also show a work-related pattern.

Before further interpreting the results, it is important that the methodological limitations are discussed. First, with 87 cases of work-related respiratory disease observed at the factory, the size of the control group $(\mathrm{n}=50)$ may seem rather low. The number of controls had to be decided at the start of the investigation as the data collection had to happen for all at the same time, before the remedial action at the factory commenced. At that time the number of known (index) cases of EAA was only 12 and we were unaware of any cases of OA, so the sample size of 50 controls was thought to be reasonable. Second, a lower proportion of the control group worked in the manufacturing area compared with cases of OA and EAA and, as a consequence, they had less potential to be exposed to MWF. This was because the control population was selected from the asymptomatic workers identified from the screening questionnaire. The selection bias in the control group probably does not affect the results presented in this paper, as the focus of the paper is more about the epidemiology of those with respiratory illness. The results from this control group does reaffirm that working in the manufacturing area is associated with an increased risk of disease.

Another methodological issue is that the date of onset of symptoms was established retrospectively from the

\section{_ Unused metal working fluid \\ - Used metal working fluid (indirect exposure) \\ $\checkmark$ Used metal working fluid (direct exposure)}

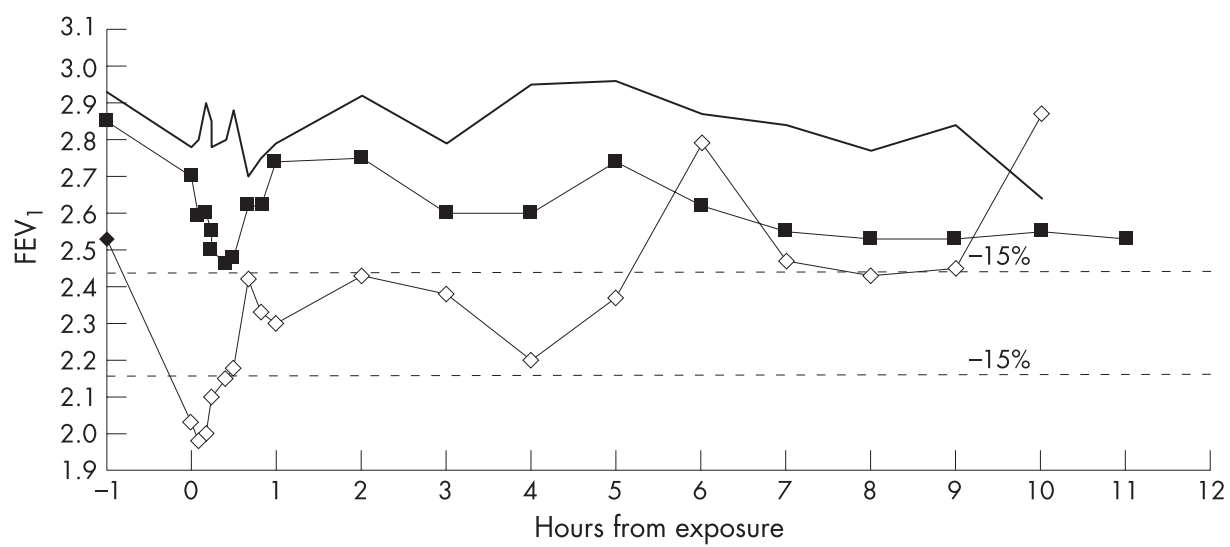

Figure 6 Bronchial provocation challenge test with unused and used metal working fluid on a worker with occupational asthma. $\mathrm{FEV}_{1}$, forced expiratory volume in $1 \mathrm{~s}$. 
self-completed questionnaire more than 15 months after the onset of the outbreak. Only 70 of the 146 workers with workrelated breathlessness were able to identify the month of onset. There were no contemporary surveillance data. With these caveats, there appears to be a peak incidence in March 2003, just before a new hydraulic oil for metal working machines was introduced in April 2003. The new hydraulic oil was more soluble in the MWF, increasing the concentration of tramp oil in the MWF. However, as the change in hydraulic oil occurred after the start of the outbreak, there is no clear evidence that this change is significant. The outbreak also coincided with reports of increased misting in the factory during the winter period when the roof louvers were closed.

Although factory records historically showed little bacterial growth, our own microbiological investigations in the factory found Acinetobacter spp and Ochrabactrum anthropi cultured from the washer fluid. DNA from these bacteria was also identified in the MWF from the largest sump, although there was no culture. No Mycobacterium spp were identified either from culture or from DNA extraction. The Health and Safety Laboratory has carried out a parallel immunological investigation of the workers at the factory in the current investigation which is reported in detail elsewhere. ${ }^{20}$ MWF from the largest common sump at the time of the outbreak and extracts from cultures of Acinetobacter spp, Ochrobactrum anthropi and Mycobacterium spp were used to look for the presence of precipitating antibodies. ${ }^{20}$ In those with EAA, 59\% had precipitating antibodies to at least one of the microbial species Acinetobacter or Ochrobactrum or to used sump oil, whereas precipitating antibodies were found in only $10 \%$ of those with OA and $5 \%$ of asymptomatic workers (controls). ${ }^{20}$ This is unlike other outbreaks of alveolitis where precipitating antibodies are commonly found in affected and asymptomatic subjects. ${ }^{27}$ No workers tested positive for precipitating antibodies to Mycobacteria species. These results indicate that bacterial contamination of MWF-and in particular Acinetobacter-had at least a contributory role in the cases of EAA.

The overall levels of mist from both MWF and mineral oil sources were unremarkable, with most levels below the then MWF guidance value of $1 \mathrm{mg} / \mathrm{m}^{3}$ and the mineral oil in air guidance value of $3 \mathrm{mg} / \mathrm{m}^{3} .^{23}{ }^{24}$ The Health and Safety Executive (the UK regulatory body for health and safety) has since withdrawn these guidance values. ${ }^{28}$

The highest number of cases was in one of the assembly areas which was about 30 metres from the common sump, suggesting that the causative aerosol was relatively widespread. Two washers vented inside the factory and were also in the northern end of the factory. Given the wide distribution of disease in the factory, the most likely cause was an aerosol from either the metalworking and/or washing operations, although no material within this mist has been confirmed as a specific causal agent.

The potential of other exposure factors as a cause of this outbreak was considered. Metal particles can produce an intrapulmonary inflammatory response ${ }^{29}$ and some specific metals are well recognised causes of OA. These are mainly platinum salts, chrome, cobalt and, to a lesser extent, zinc and nickel. At the factory the engines were made of aluminium alloy. There was no platinum, chrome or nickel. There was one machine where hard metal valve rings were machined. Cobalt levels in the MWF were insignificant and levels were checked in the urine of workers and were normal. There is some doubt as to whether aluminium alone can cause OA. The main work on aluminium and asthma comes from smelters where aluminium sodium fluoride is a possible cause. It has never been described in those working with cold aluminium. There were no sources of nitrogen oxides (no heating of the metal). However, the potential for other chemical constituents to be either causal or to have had a co-effect cannot be discounted. The Health and Safety Executive has compiled a list of the constituents and contaminants of the MWF and wash fluids at the factory which were considered in the original investigation as possible causes of either EAA or OA ( see online supplement available at http:// thorax.bmj.com/supplemental).

During bronchial challenge tests two workers (one with OA and one with EAA) confirmed reactions to the used MWF taken from the common sump but not the clean MWF. The used MWF will contain material from the aluminium alloy castings, microbial contamination and added biocides, $\mathrm{pH}$ adjusters, etc. The lack of reaction to the unused MWF indicates that the chemical constituents alone were unlikely to have caused the disease.

As a consequence of this outbreak UK policy has changed, firstly for the users of MWF and secondly for those affected by EAA. First, the "lessons learned" from this outbreak have been published by the Health and Safety Executive on their website (this is available in the online Appendix at http://thorax.bmj. com/supplemental), detailing the practical implications for other users of MWF. ${ }^{28}$ This outbreak showed that adhering to the guidance standards of oil mist did not prevent respiratory disease $^{2324}$ and has led to their withdrawal by the Health and Safety Executive. Furthermore, the Health and Safety Executive has since issued new guidance on safe working practices that includes a requirement for respiratory surveillance. They have subsequently carried out a national survey of large users of MWF in 2005/6 to identify the extent to which guidance was being followed, with many deficiencies noted..$^{30}$

Second, there is an anomaly in that OA due to oil mists is compensatable in the UK through a no-fault compensation system from the UK Government's Department for Work and Pensions, but EAA due to anything other than fungal or avian antigens is not. ${ }^{31} \mathrm{OA}$ is known to adversely affect income and clinical outcome, ${ }^{32}{ }^{33}$ whereas the impact of EAA is likely to be at least as important. In July 2006 the Industrial Injuries Advisory Council (who advise the Department of Work and Pensions of the list of prescribed diseases for compensation) recommended that the occupational coverage for EAA should include exposure to mists from MWF. ${ }^{34}$ This has now had ministerial approval and "Work involving exposure to MWF" as a cause of EAA was added to the list of prescribed diseases on 6 April 2007. ${ }^{31}$

Finally, it is of interest to note what happened after the outbreak at the factory. After the assessment at the factory in June 2004 a series of control measures was introduced including: $:^{28}$

- replacing MWF in the large common sumps;

- cleaning machines with individual sumps (both metalworking and washing) which were heavily contaminated with bacteria and then refilling them with fresh fluid;

- treating other less contaminated sumps with biocide;

- supplying employees with respiratory protection with powered respirators for those with known disease; and

- instituting respiratory surveillance for all employees.

Continued surveillance using occupational PEF records was carried out for those with OA, and a few had persistent OA despite the extensive control measures. The factory went into administration in April 2005. The machinery was subsequently bought by Nanjing Automobile (Group) Corporation and removed to China. Nanjing has been warned about the risks.

\section{CONCLUSIONS}

This investigation of an outbreak of EAA in a car manufacturing plant detected a large number of affected workers-not 
only EAA but also OA-and is the largest reported outbreak in Europe. Mist from used MWF is the likely cause although oil mist levels were generally below guidance values, emphasising that it was time to reconsider the standards and issue new guidelines. Our study suggests that, in workplaces using MWF and wash fluids, there is a need to carry out risk assessments, ensure that fluid quality is monitored and maintained, improve the control of mist and carry out respiratory health surveillance on exposed workers.

\section{ACKNOWLEDGEMENTS}

The authors acknowledge and thank Professor Tony Pickering, Geraldine Bale, Dr Clara Dawkins, Dr Angela Fletcher and Dr Fred Bio for their invaluable support with the factory based assessment, Rowan Campbell for data entry, Dr Richard Southam and the factory management for their administrative support.

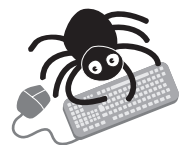

Additional information is given in the online supplement available at http://thorax.bmi.com/ supplemental

\section{Authors' affiliations}

W Robertson, Department of Public Health, Health Sciences Research Institute, Warwick Medical School, University of Warwick, Coventry, UK A S Robertson, C B S G Burge, V C Moore, P S Burge, Occupational Lung Disease Unit, Birmingham Heartlands Hospital, Birmingham, UK M S Jaakkola, Institute of Occupational and Environmental Medicine, University of Birmingham, Birmingham, UK

P A Dawkins, Department of Medicine, University of Birmingham, Birmingham, UK

M Burd, R Rawbone, I Gardner, M Kinoulty, Health and Safety Executive, Birmingham, UK

B Crook, G S Evans, J Harris-Roberts, S Rice, Health and Safety

Laboratory, Buxton, UK

Data entry was funded by the company.

Competing interests: None declared.

\section{REFERENCES}

1 Proudfit JP, van Ordstrand HS, Miller CW. Chronic lipoid pneumonia following occupational exposure. Ann Ind Hyg Occup Med 1950;1:105-11.

2 Foe RB, Bigham RS Jr. Lipid pneumonia following occupational exposure to oil spray. J Am Med Assoc 1954;155:33-4

3 Cullen MR, Balmes JR, Robins JM, et al. Lipoid pneumonia caused by oil mist exposure from a steel rolling tandem mill. Am J Ind Med 1981;2:51-8.

4 Hendy MS, Beattie BE, Burge PS. Occupational asthma due to an emulsified oil mist. Br J Ind Med 1985:42:51-4.

5 Robertson AS, Weir DC, Burge PS. Occupational asthma due to oil mists. Thorax 1988:43:200-5.

6 Greaves IA, Eisen EA, Smith TJ, et al. Respiratory health of automobile workers exposed to metal-working fluid aerosols: respiratory symptoms. Am J Ind Med 1997; 32:450-9.

7 Massin N, Bohadana AB, Wild $P$, et al. Airway responsiveness, respiratory symptoms, and exposures to soluble oil mist in mechanical workers. Occup Environ Med 1996;53:748-52.

8 Kennedy SM, Chan-Yeung M, Teschke K, et al. Change in airway responsiveness among apprentices exposed to metalworking fluids. Am J Respir Crit Care Med 1999:159:87-93.

9 Sprince NL, Thorne PS, Popendorf W, et al. Respiratory symptoms and lung function abnormalities among machine operators in automobile production. Am J Ind Med 1997;31:403-13.
10 Kriebel D, Sama S, Woskie S, et al. A field investigation of the acute respiratory effects of metal working fluids: I. Effects of aerosol exposures. Am J Ind Med 1997:31:756-66.

11 Kennedy SM, Greaves IA, Kriebel D, et al. Acute pulmonary response among automobile workers exposed to aerosols of machine fluids. Am $J$ Ind Med 1989;15:627-41

12 Robins R, Seixas N, Flanzblau A, et al. Acute respiratory effects on workers exposed to metalworking fluid aerosols in an automotive transmission plant. Am J Ind Med 1997:31:510-24.

13 Eisen EA, Smith TJ, Kriebel D, et al. Respiratory health of automobile workers and exposure to metal-working fluid aerosols: lung spirometry. Am J Ind Med 2001;39:443-53.

14 Bernstein DI, Lummus ZL, Santilli G, et al. Machine operator's lung: a hypersensitivity pneumonitis disorder associated with exposure to metalworking fluid aerosols. Chest 1995; 108:636-41.

15 Centers for Disease Control and Prevention. Biopsy-confirmed hypersensitivity pneumonitis in automobile production workers exposed to metalworking fluids Michigan, 1994-1995. Morb Mortal Wkly Rep 1996;45:606-10.

16 Fox J, Anderson H, Moen T, et al. Metal working fluid-associated hypersensitivity pneumonitis: an outbreak investigation and case-control study. Am J Ind Med 1999;35:58-67.

17 Hodgson MJ, Bracker A, Yang C, et al. Hypersensitivity pneumonitis in a metalworking environment. Am J Ind Med 2001;39:616-28.

18 Dawkins P, Robertson A, Robertson W, et al. An outbreak of extrinsic alveolitis at a car engine plant. Occup Med (Lond) 2006;56:559-65.

19 Quanjer PH, Tammeling GJ, Cotes JE, et al. Lung volumes and forced ventilatory flows. Report Working Party. Standardisation of lung function tests, European Community for Steel and Coal. Official Statement of the European Respiratory Society. Eur Respir J 1993;6(Suppl 16):5-40.

20 Naylor S, Barber C, Crook B, et al. Powertrain occupational respiratory disease outbreak: report of immunological investigation. Health and Safety Laboratory Report MU/06/01 (Internal), 2006.

21 Anees W, Gannon PF, Huggins V, et al. Effect of peak expiratory flow data quality on diagnostic sensitivity and specificity in occupational asthma. Eur Respir J 2004;23:730-4.

22 Gannon PF, Newton DT, Belcher J, et al. Development of OASYS-2: a system for the analysis of serial measurements of peak expiratory flow in workers with suspected occupational asthma. Thorax 1996:51:484-9.

23 Health and Safety Executive. Measurement of personal exposure of metalworking machine operators to airborne water-mix metalworking fluid, 2003, MDHS 95/2. www.hse.gov.uk/pubns/mdhs95-2.pdf (accessed 10 August 2006).

24 Health and Safety Executive. Working safely with metalworking fluids. Good practice manual, HS(G) 231, HSE Books, 2002.

25 Perrin B, Lagier F, L'Archeveque J, et al. Occupational asthma: validity of monitoring of peak expiratory flow rates and non-allergic bronchial responsiveness as compared to specific inhalation challenge. Eur Respir J 1992;5:40-8.

26 Zacharisen MC, Kadambi AR, Schlueter DP, et al. The spectrum of respiratory disease associated with exposure to metal working fluids. J Occup Environ Med 1998;40:640-7.

27 Bourke SJ, Dalphin JC, Boyd G, et al. Hypersensitivity pneumonitis: current concepts. Eur Respir J 2001;18(Suppl 32):81-92S.

28 Health and Safety Executive. Outbreak of respiratory disease at Powertrain Ltd, Longbridge, Birmingham. Emerging lessons, Health and Safety Executive, 2006. www.hse.gov.uk/metalworking/experience/powertrain.pdf (accessed 28 March 2007).

29 Schaumann F, Borm PJA, Herbrich A, et al. Metal-rich ambient particles (particulate matter 2.5) cause airway inflammation in healthy subjects. Am J Respir Crit Care Med 2004;170:898-903.

30 Health and Safety Executive. Summary of results of large metalworking fluid user project 2005-6. http://www.hse.gov.uk/metalworking/experience/ summary0506.htm (accessed 28 March 2007).

31 Department for Work and Pensions. List of diseases covered by Industrial Injuries Disablement Benefit. www.dwp.gov.uk/advisers/dbl/appendix/ appendixl.asp (accessed 12 September 2007).

32 Gannon PF, Weir DC, Robertson AS, et al. Health, employment and financial outcomes. Br J Ind Med 1993;50:491-6.

33 Anees W, Moore VC, Burge PS. FEV 1 decline in occupational asthma. Thorax 2006;61:751-5.

34 Industrial Injuries Advisory Council. Extrinsic allergic alveolitis, Report by the Industrial Injuries Council in accordance with Section 171 of the Social Security Administration Act 1992 reviewing the prescription of extrinsic allergic alveolitis for work involving exposure to mists from metalworking fluids. July 2006. www.iiac.org.uk/pdf/command_papers/Cm6867.pdf (accessed 27 March 2007). 